\title{
Seismic Stability of the Duwamish River Delta, Seattle, Washington
}

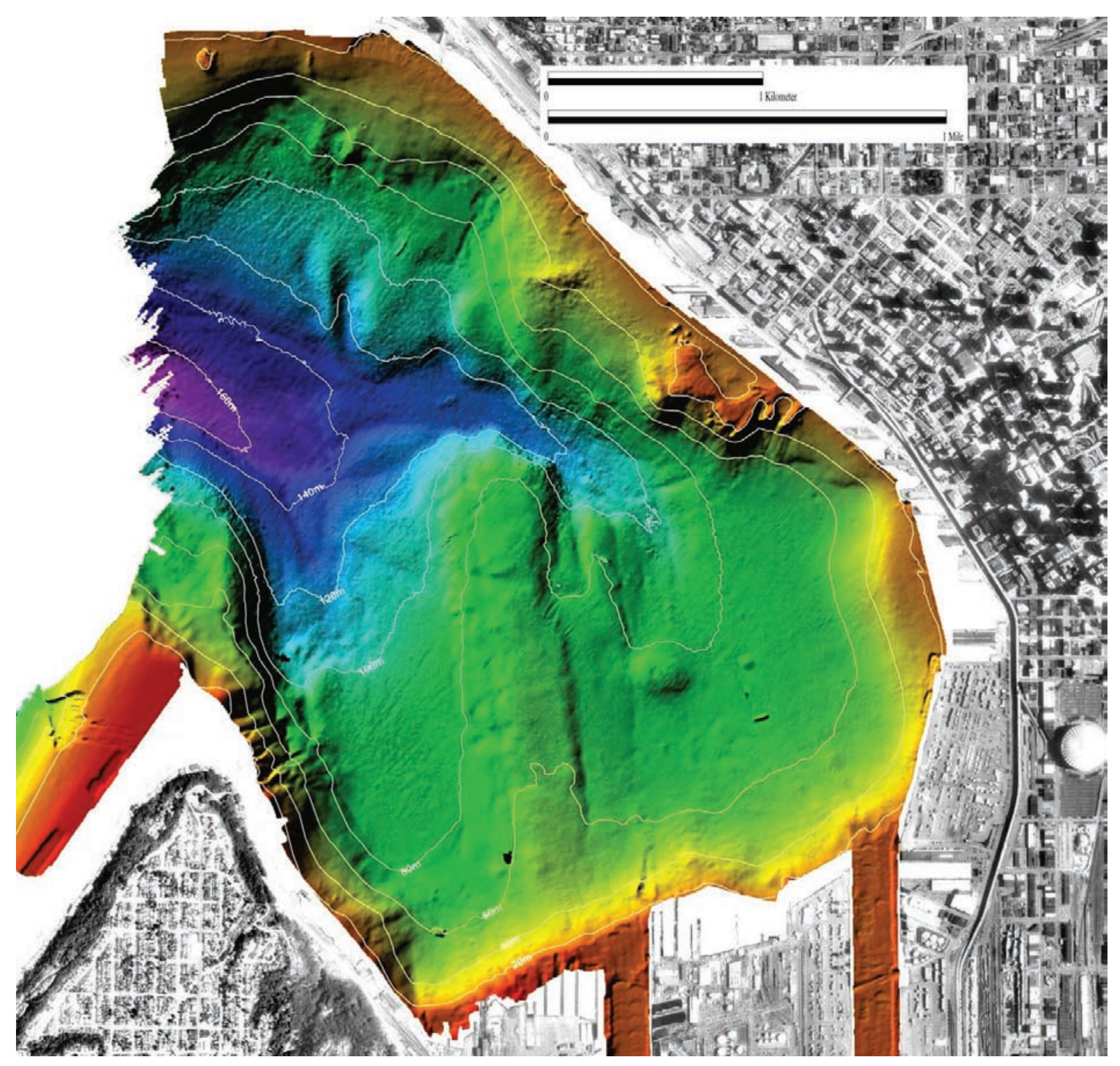

Professional Paper 1661-E 
Other than this note, this page left intentionally blank. 


\section{Earthquake Hazards of the Pacific Northwest Coastal and Marine Regions}

Robert Kayen, Editor

\section{Seismic Stability of the Duwamish River Delta, Seattle, Washington}

By Robert E. Kayen and Walter A. Barnhardt

The delta front of the Duwamish River valley near Elliott Bay and Harbor Island is founded on young Holocene deposits shaped by sea-level rise, episodic volcanism, and seismicity. These river-mouth deposits are highly susceptible to seismic soil liquefaction and are potentially prone to submarine landsliding and disintegrative flow failure.

Professional Paper 1661-E 


\section{U.S. Department of the Interior \\ DIRK KEMPTHORNE, Secretary}

\section{U.S. Geological Survey \\ Mark D. Myers, Director}

U.S. Geological Survey, Reston, Virginia: 2007

This report and any updates to it are available at:

http://pubs.usgs.gov/pp/pp1661e/

For product and ordering information:

World Wide Web: http://www.usgs.gov/pubprod

Telephone: 1-888-ASK-USGS

For more information on the USGS — the Federal source for science about the Earth, its natural and living resources, natural hazards, and the environment:

World Wide Web: http://www.usgs.gov

Telephone: 1-888-ASK-USGS

Manuscript approved for publication, May 29, 2007

Text edited by Peter Stauffer

Layout by David R. Jones

Suggested citation:

Kayen, R.E., and Barnhardt, W.A., 2007, Seismic stability of the Duwamish River delta, Seattle, Washington:

U.S. Geological Survey Professional Paper 1661-E, 11 p.

Any use of trade, product, or firm names is for descriptive purposes only and does not imply endorsement by the U.S. Government.

Although this report is in the public domain, permission must be secured from the individual copyright owners to reproduce any copyrighted materials contained within this report.

\section{Cataloging-in-publication data are on file with the Library of Congress (http://www.loc.gov/).}




\section{Contents}

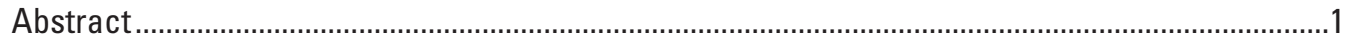

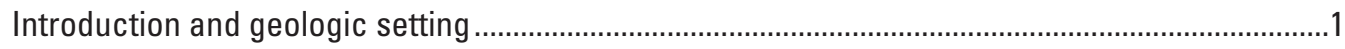

Sediment supply

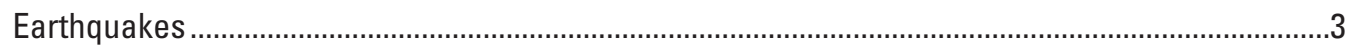

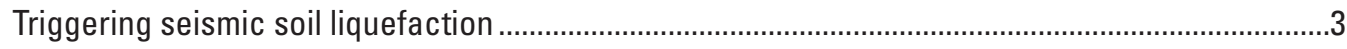

Disintegrative flow failure potential .......................................................................................

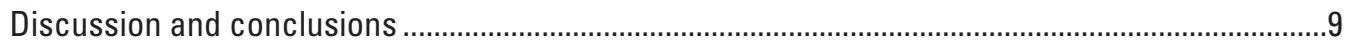

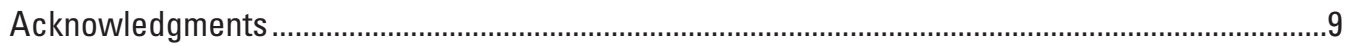

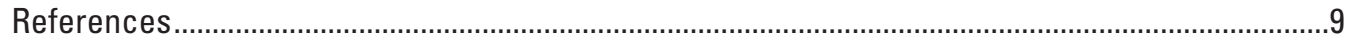

\section{Figures}

1. Map of the Puget Sound region, showing locations of major fault zones and three major river deltas

2. Model of Holocene evolution of the Duwamish delta and the influence of episodic volcanism

3. Diagram of idealized structure of the Duwamish River delta at Elliott Bay before industrial development

4. Diagrams showing assessment of initial liquefaction using earthquake-induced cyclic stress or Arias intensity.

5. Geographic Information Systems (GIS) plots showing the distribution of factor of safety interpolated from seven boreholes arrayed on the Duwamish River delta at Elliott Bay.

6. Diagrams illustrating the behavior of soils, after liquefaction during an earthquake, under different conditions of stress, strain, and porosity......

7. Cross-sectional diagram showing state analysis of the Duwamish delta front along the B1-B7 profile parallel to shore. 
Other than this note, this page left intentionally blank. 


\title{
Seismic Stability of the Duwamish River Delta, Seattle, Washington
}

\author{
By Robert E. Kayen' and Walter A. Barnhardt ${ }^{2}$
}

\begin{abstract}
A highly developed commercial-industrial corridor, extending from the City of Kent to the Elliott Bay/Harbor Island marine terminal facilities, is founded on the young Holocene deposits of the Duwamish River valley. The deposits of this Holocene delta have been shaped not only by relative sea-level rise but also by episodic volcanism and seismicity. Ground-penetrating radar (GPR), cores, in situ testing, and outcrops are being used to examine the delta stratigraphy and to infer how these deposits will respond to future volcanic eruptions and earthquakes in the region. A geotechnical investigation of these river-mouth deposits indicates high initial liquefaction susceptibility during earthquakes, and possibly the potential for unlimited-strain disintegrative flow failure of the delta front.
\end{abstract}

\section{Introduction and Geologic Setting}

This paper examines the geomorphology and seismic stability of the Duwamish River delta at the Port of Seattle in western Washington State. This river, and those forming the two principal Holocene deltas to the south, the Puyallup and Nisqually Rivers, originate on the slopes of Mount Rainier, a large and active stratovolcano of the Cascade Range, and flow into southern Puget Sound (fig. 1). Fluvial sediment derived from extensive drainages in this volcanic terrain has formed thick young deltaic deposits, which record a complex sequence of valley fill. Our main objective is to determine how volcanoes and earthquakes have affected the evolution of Holocene deltas in Puget Sound and to evaluate the potential for the natural deposits that comprise the Duwamish River delta to undergo initial liquefaction and associated large-strain flow failure.

The development of river systems in the Puget Lowland has been strongly influenced by the preexisting topography and tectonic setting of the region. Multiple glaciations in Quaternary time greatly modified the landscape, covering it with thick glacigenic deposits and sculpting deep, linear troughs

\footnotetext{
${ }^{1}$ Menlo Park, California

${ }^{2}$ Woods Hole, Massachusetts
}

comprising many present-day lakes and the numerous arms of Puget Sound (Booth, 1994). Subaerial segments of the glacial valleys are now occupied by rivers, which deliver abundant sediment to the heads of laterally constrained marine embayments. Holocene deltas in these embayments became choice sites for industry and commerce in Seattle and Tacoma.

The Duwamish River, before engineering modifications at the start of the 20th century, was a natural distributary channel of the Cedar and Green Rivers, as well as at times the White River. These rivers originate on the flanks Mount Rainier, a large active stratovolcano of the Cascade Range. After deglaciation, a fjord canyon occupied the present location of the Duwamish River valley. This was rapidly infilled since the mid-Holocene, largely by sediment derived from Mount Rainier. Episodic volcaniclastic debris flows (lahars) from Mount Rainier caused the delta front to prograde rapidly towards its present position at the southeast end of Elliott Bay (fig. 1).

The nearby city of Vancouver, British Columbia, lies in a similar deltaic setting. Although the deltas suffered little damage during deep earthquakes that struck in the middle 1900 s, they may be subject to greater damage from recently discovered sources of earthquakes in the Puget Sound area. Chief among these additional sources are the Seattle Fault, which directly underlies the Duwamish delta (fig. 1), and the boundary between the subducting Juan de Fuca Plate and the overriding North America Plate, which is at a depth of about $50 \mathrm{~km}$ beneath the City of Seattle.

\section{Sediment Supply}

Abundant sediment supply from Mount Rainier, including lahars (volcanic debris flows), has fueled rapid progradation of Holocene deltas in southern Puget Sound (Dragovich and others, 1994; Barnhardt, and others, 1998). Landslides and debris flows, not necessarily attended by eruptions, produce lahars that occasionally choke river channels and blanket valley bottoms with sediment (Scott and others, 1995). The largest known of these events was the Osceola Mudflow (Crandell, 1971; Vallance \& Scott, 1997), which occurred approximately 5,700 years ago and covered $505 \mathrm{~km}^{2}$ of the Puget Lowland with cohesive lahar deposits up to $31 \mathrm{~m}$ thick. On the basis of numerous soil borings, Dragovich and others (1994) traced 


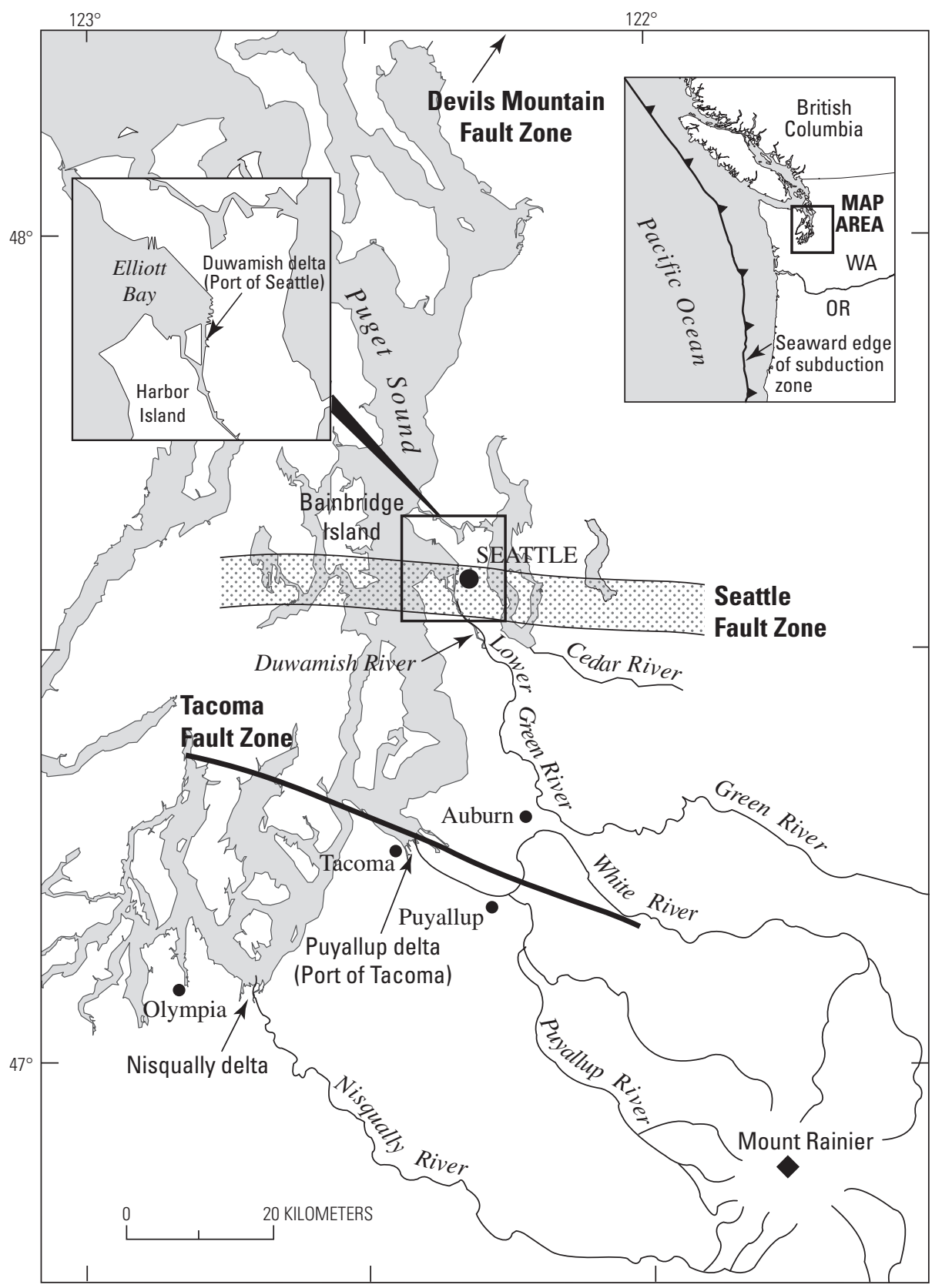

Figure 1. Map of the Puget Sound region, showing locations of major faults and three major river deltas. The Duwamish River delta is located at Elliot Bay in the City of Seattle and is underlain by the Seattle Fault Zone.

the Osceola Mudflow within Holocene valley fill. Using the distinctive mudflow deposits as a stratigraphic marker, they estimated that the Duwamish and Puyallup deltas have grown seaward 51 and $14 \mathrm{~km}$, respectively, since that time (fig. 2). These high progradation rates ( 9.0 and $2.5 \mathrm{~m} / \mathrm{yr}$, respectively) are similar to that of the Fraser River delta (2.4-6.5 m/yr), which for much of its history was also confined to a valley of limited width (Williams and Roberts, 1989).

Other middle to late Holocene lahars also contributed abundant sediment to the Duwamish, Puyallup, and Nisqually Rivers (Scott and others, 1995). These sandy lahar deposits have a strong influence on groundwater and engineering properties of the valley soils, yet their full extent is poorly known.
For example, deposits of massive, coarse sand that occur in the Puyallup Valley clearly originated as lahars (Pringle and Palmer, 1992). The sands consist of angular grains having a volcanic provenance, based on mineralogy and the presence of scoria, pumice, and lapilli. Small twigs from the lahar sand deposit yielded an uncorrected age of 2,320 $\pm 120{ }^{14} \mathrm{C}$ yr BP (Palmer and others, 1991), which is time correlative with a block-and-ash-flow deposit in the upper Puyallup valley (Crandell, 1971). Cores and trench exposures $65 \mathrm{~km}$ downstream of Mount Rainier indicate this lahar flood deposit is as much as $7.5 \mathrm{~m}$ thick and represents a significant volume of rapidly deposited sediment (Palmer and others, 1991; Pringle and Palmer, 1992). 

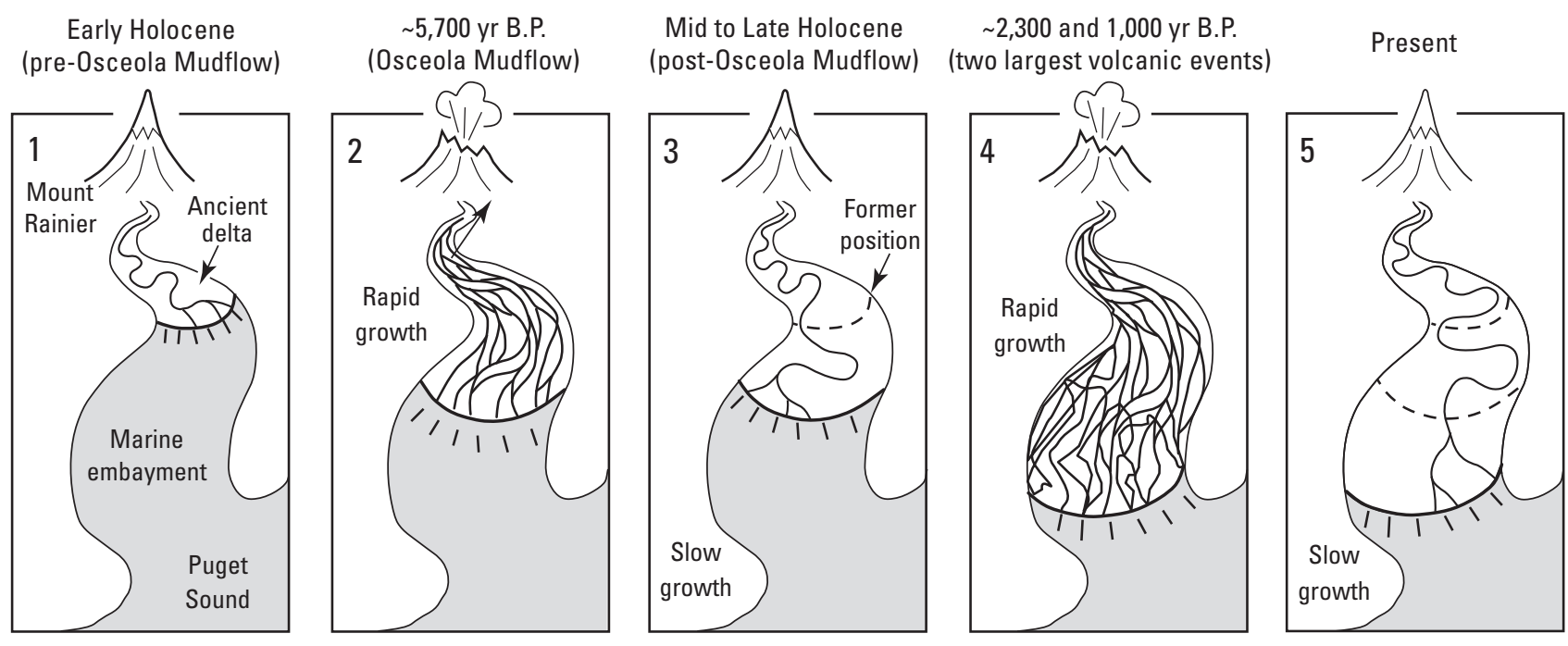

Figure 2. Model of Holocene evolution of the Duwamish delta and the influence of episodic volcanism.

\section{Earthquakes}

Although the central Puget Sound region has been historically quiescent, abundant evidence exists for a large earthquake there about 1,000 years ago. A raised marine platform on Bainbridge Island, $5 \mathrm{~km}$ west of Seattle (fig. 1), indicates $7 \mathrm{~m}$ of sudden, coseismic uplift during this event (Bucknam and others, 1992). In addition, subaqueous landslides (Jacoby and others 1992; Karlin and Abella, 1992) and tsunamis (Atwater and Moore, 1992) are apparently related to prehistoric movement along the Seattle Fault Zone, a major reverse fault that passes directly beneath the Duwamish delta and downtown Seattle (Johnson and others, 1994; fig. 3). Tectonic displacement along this fault is also suggested by uplifted, shell-rich deposits that are observed several meters above the high-tide level (Campbell, 1981). These raised estuarine sediments are capped with a thick layer (locally greater than $3 \mathrm{~m}$ ) of black, well-sorted sand (Campbell, 1981). Pringle and others (1997) inferred a volcanic origin (reworked lahars) for these surficial deposits of clean sand, which probably correlate with upstream deposits of the Deadman Flat lahar assemblage $\left(\sim 1,000{ }^{14} \mathrm{C}\right.$ yr BP $)$. These deposits are displayed at the surface by swarms of liquefaction dikes from prehistoric ground failure in the Duwamish along the Duwamish waterway at and near Kellogg Island. The dikes intrude tidal-marsh deposits that postdate the uplift along the Seattle Fault 1,000 years ago. Some of the dikes can be traced upward to lenses of silty sand that are probably the flanks of vented-sand volcanoes (sand boils) erupted from the dikes. The largest of the dikes is as much as $18 \mathrm{~cm}$ wide and at least $6 \mathrm{~m}$ long. They contain dark, fine to medium sand that becomes finer grained upwards and resembles sand derived from Mount Rainier.

Other known sources of strong motion for the Puget Lowland capable of triggering ground failures in the sediment of the Duwamish River include the Tacoma Fault to the south, and the Cascadia megathrust (Brocher and others, 2000, 2001). Tensional faulting within the downgoing slab of the Casadia megathrust was the source of the $M 6.8$ Nisqually earthquake event of February 28, 2001 (Bray and others, 2001; Filiatrault and others, 2001; Nisqually Earthquake Clearinghouse Group, 2001). Considerably further away from, and northward of, the Duwamish Valley is the Devils Mountain Fault Zone (Johnson and others, 2001).

\section{Triggering Seismic Soil Liquefaction}

Liquefaction of deltaic deposits of the Duwamish River valley during earthquakes of moderate to large magnitude can have severely adverse affects on structures and lifelines. Liquefaction damage often leads to separation of pipeline conduits, settlement of foundations, bearing-capacity failure, lateral movement of ground and bridge piers, and uplift of storage tanks and other positively buoyant structures. Initial liquefaction, the transient increase in pore-water pressures and corresponding loss of effective confining stress and soil strength, results in soil behaving in a fluidlike manner, with the potential for large strain deformation (disintegrative flow failure). In some cases, disintegrative flow failure of ground following initial liquefaction has led to catastrophic landslides on sloping land, embankments, and earth dams.

To characterize the geotechnical properties of the subsurface delta, standard penetration test (SPT) and cone penetration test (CPT) data are used. Following the guidelines of Seed and his colleagues $(1983,1984)$, Cetin and others (2004), and Moss and others (2006). We use the effective-stressnormalized, 60-percent energy efficiency standard penetration resistance $\left(N_{1}\right)_{60}$ for liquefaction assessment. In our study, we currently use SPT and CPT data made available by others working on local site investigations of Duwamish River 


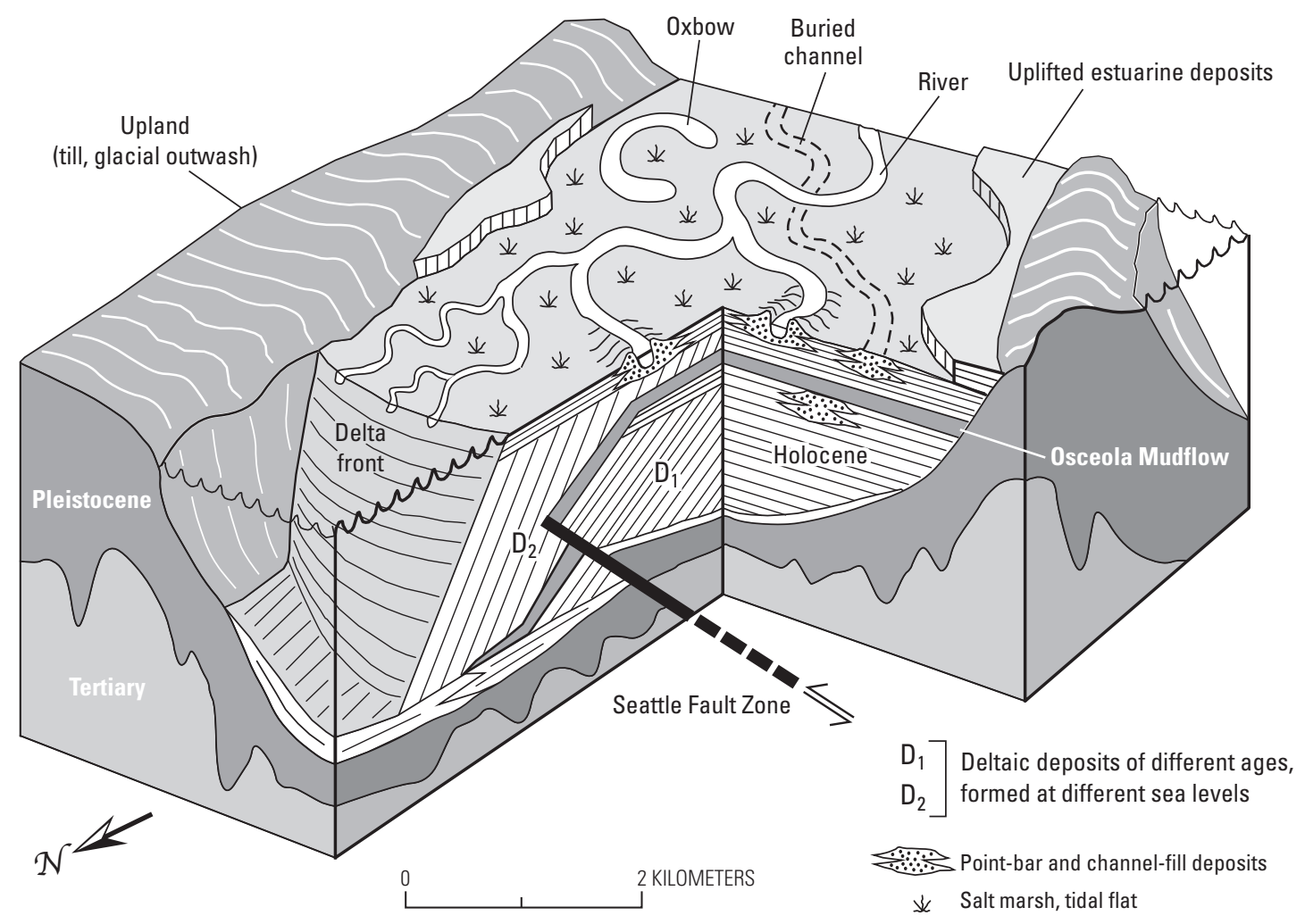

Figure 3. Idealized structure of the Duwamish River delta at Elliott Bay before industrial development (vertical exaggeration $20 x$ ). The Seattle Fault here is blind, not exposed.

soils (unpublished Report 3528 by Hart Crowser, Inc., 1910 Fairview Avenue East, Seattle, WA 98102-3699, 1993).

Liquefaction typically occurs in sandy, water-saturated soils such as flood-plain deposits, delta deposits, alluvial sediments, and landfill. Much of the worst damage from the 1989 Loma Prieta, California, earthquake and the 1995 Kobe, Japan, earthquake resulted from settlement and collapse of port facilities where the soil beneath them liquefied. During earthquake shaking, water pressure in tiny spaces, or pores, within the soil is elevated temporarily, commonly for only a matter of seconds or minutes. These high pore pressures can fully negate interparticle contact stresses, resulting in a loss of strength that can potentially cause the soil to flow like a liquid. Soil that had previously supported large structures cannot support them when it is in a liquefied state. The cause of these excess pore pressures during shearing is the tendency towards fabric collapse and volumetric reduction of pore space in loose soils. Fabric collapse of the soil grain skeleton loads the pore water of the soil interstices. If the collapse occurs more rapidly than the soil can dissipate excess water pressures, as in the case of earthquake shaking, water pressure can rise while the corresponding particle contact stresses proportionally drop. In contrast, dense soils tend either to not generate high excess pore water pressures, or to rapidly regain strength with minor levels of deformation. Initial liquefaction
(National Research Council, 1985; Youd and others, 2001) occurs when elevated pore pressures, in excess of hydrostatic, reduce the effective stresses acting on an undeformed cohesionless soil mass to zero.

The liquefaction potential of a soil deposit tends to decrease with increasing age of the deposit, degree of particle cementation, and depth to the water table. Each of the above factors tends to densify the soil structure, increase rigidity, and reduce the potential for generation of high pore pressure (Youd and Perkins, 1978). At the Duwamish River delta, a preponderance of factors, including extremely young and thick deposits of sand, rapid deposition, and high water table, have resulted in the formation of a loose deposit that is highly susceptible to generation of excess pore water pressure during earthquakes.

For the assessment of initial liquefaction potential at the delta front we used SPT data collected at each of the soil boring sites offshore Harbor Island. These measurements, a proxy for soil residual strength, were then related to measures of the intensity of earthquake shaking likely to affect the delta front. Two approaches were used to assess the intensity of seismic shaking at the study sites: (1) the conventional cyclic stress method (CSR) of Seed and others (1984) and Cetin and others (2004) and (2) an approach using the Arias intensity of ground motion of Kayen and Mitchell (1997). The first method 
employed a simplified uniform cyclic stress ratio to represent the complex and irregular earthquake-induced stress-time history. The second approach employed a quantitative measure of earthquake shaking intensity, termed Arias intensity. The Arias intensity measure is the sum of the energy-per-unit weight absorbed by an evenly spaced population of idealized undamped simple oscillators in response to the earthquake motion (Kayen and Mitchell, 1997).

In assessment of seismic soil liquefaction triggering, we associate CSR and Arias intensity $\left(I_{h b}\right)$ profiles with the SPT liquefaction field performance data, $\left(N_{1}\right)_{60}$, from the soil boring sites using two SPT-based boundary curve correlations for the assessment of soil liquefaction potential (fig. 4). The CSR and $I_{h b}$ at the liquefaction boundary in figure 4 represent the minimum threshold seismic intensity required to induce liquefaction in soil. The CSR curves presented in figure $4 A$ show the probability (likelihood) of liquefaction for a magnitude 7.5 earthquake for sandy soil with 5 percent or less silt and clay particles. We compared the minimum level of shaking intensity needed to liquefy soil of a given $\left(N_{1}\right)_{60}$ with the likely intensity of shaking induced by an earthquake affecting the Duwamish River delta to determine the factor of safety against initial liquefaction. Computed factors of safety in excess of 1.0 indicate liquefaction is unlikely given the design-basis earthquake, whereas values equal to or below 1.0 indicate that liquefaction is likely. Results from the stress-based and Arias-intensity-based analysis are presented here as crosssections along the line of cores (fig. 5). For a $M 7+$ earthquake, with accelerations of $0.2 \mathrm{~g}$ and greater, there is a broad zone extending to a subbottom depth of approximately $20 \mathrm{~m}$ that is predicted to liquefy. The $M 6.8$ Nisqually earthquake of February 28,2001 , produced accelerations of approximately $0.2 \mathrm{~g}$ on Harbor Island, resulting in numerous liquefaction related features on the surface, ground settlement and lateral displace- ments (Bray and others, 2001). Given the proximity of the delta front to the Seattle Fault, which passes directly beneath it (Johnson and others, 1994), and other sources, the potential for surface ground motions to reach above the $0.2-g$ range of the Nisqually earthquake event is considered to be guaranteed. The 1996 Pacific Northwest map of 2-percent exceedance probability for peak acceleration in the next 50 years, developed by the U.S. Geological Survey National Seismic Hazards Mapping Project, predicts accelerations at approximately a 0.6- $g$ level for the Duwamish Delta.

\section{Disintegrative Flow Failure Potential}

Liquefaction susceptibility analyses, like those of Seed and others (1983), Cetin and others (2004), and Kayen and Mitchell (1997), predict the conditions of transient porepressure rise and initial liquefaction, and the breakdown of soil structure to a residual strength state. However, other means must be used to shed light on how a sediment mass will behave after initial liquefaction occurs. Specifically, what is the potential for transformation of earthquake-induced liquefied material into a disintegrative flow?

The type of mass movement that occurs following the initial liquefaction involves a potential continuum of mechanical behavior ranging from limited strain-hardening deformation to unlimited viscous flow. Whitman (1985) described two ideal behavioral states, disintegrative flow failure and nondisintegrative failure. Disintegrative flow failure is a condition in which a sediment mass deforms continuously under a static shear stress (downslope gravitational stress in this case) that equals or exceeds the resistive residual shear strength of the sediment. This sediment shear resistance at high strains, $S_{r}$, has been

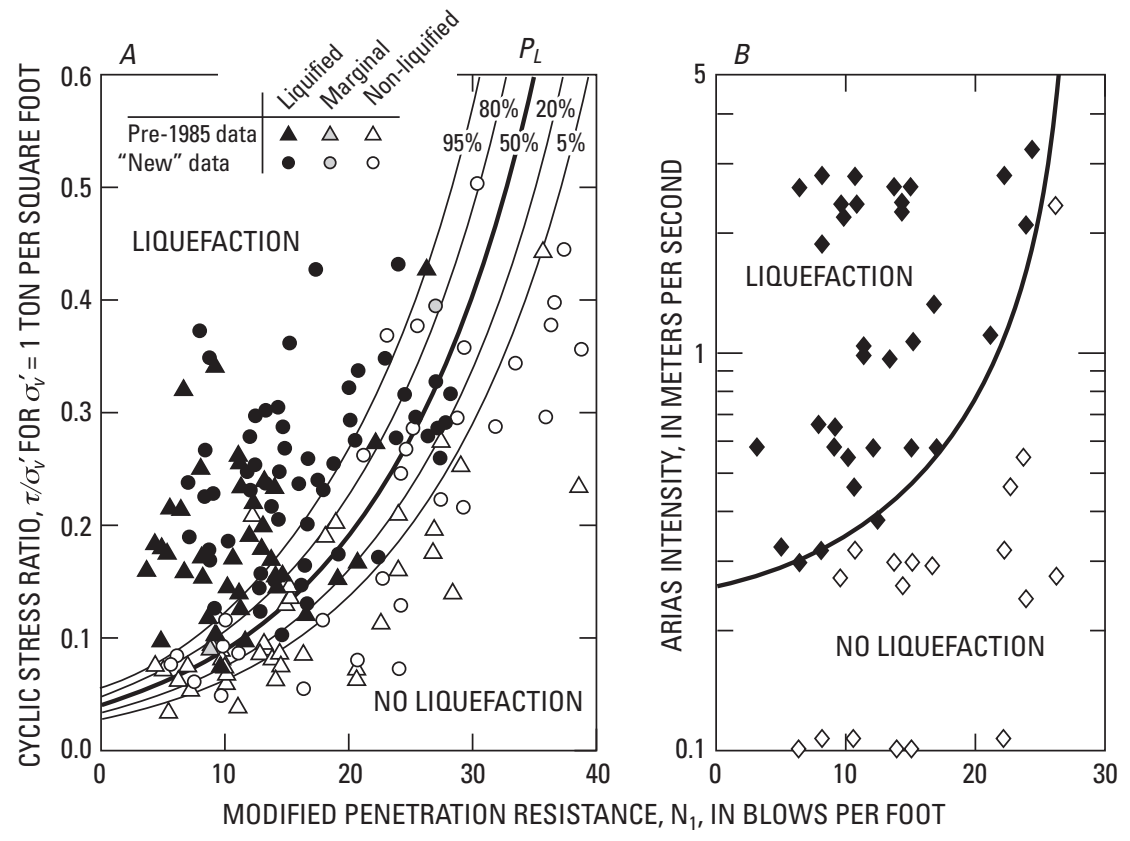

Figure 4. Initial liquefaction, the complete loss of cyclic strength and effective confining stress caused by pore-pressure rise at zero strain, can be assessed using field data and an estimated measure of either $(A)$ the earthquake-induced cyclic stress (Cetin and others, 2004) or (B) Arias intensity (Kayen and Mitchell, 1997). Both plots are presented for sand with fines content of 5 percent or less. Figure $4 A$ presents curves that show the probability of liquefaction occurrence $\left(P_{L}\right)$ between 5 and 95 percent. 

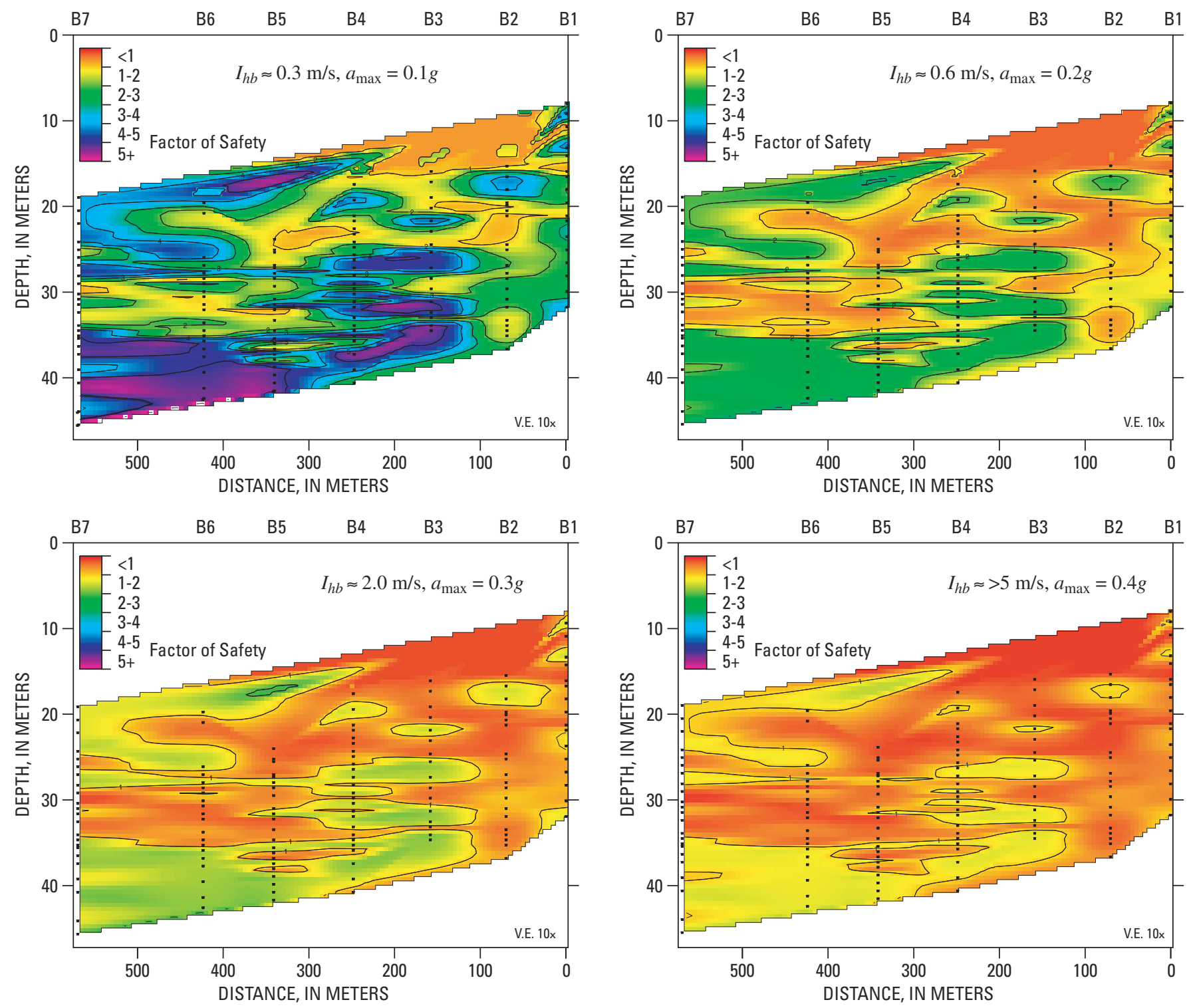

Figure 5. Geographic Information Systems (GIS) plots showing the distribution of factor of safety, under varied conditions of maximum acceleration, interpolated from seven boreholes arrayed parallel to the shoreline at Elliott Bay on the Duwamish River delta. Borehole B7 is to the east and borehole B1 is to the west. In assessing the potential for initial liquefaction, a factor of safety less than 1.0 indicates a likelihood for liquefaction. $I_{h b}$ is the Arias intensity.

referred to as steady-state shear strength (Poulos, 1981; Poulos and others, 1985) and residual strength (Seed, 1987; Seed and Harder, 1990; Baziar and Dobry, 1995). Slopes that have undergone disintegrative flow failure experience large strains such that the soil mass flows (Whitman, 1985). Nondisintegrative failure is a condition of momentary instability of a moreor-less coherent block. Soil movement (inertial deformation during earthquakes) can occur during nondisintegrative failure, but only for relatively short distances.

In order for disintegrative flow failure to occur, the residual shear strength, $S_{r}$, must be less than or equal to the downslope gravitational shear stress, $\tau_{s}$. The sediment state in which $\tau_{s} \geq S_{r}$ and in which no drainage (inflow or dissipation of pore water) occurs is referred to as State I (Whitman, 1985). According to Whitman (1985), a disintegrative flow is possible under locally undrained conditions (constant volume) only if the sediment is in State I.

Within State II sediment, the residual shear strength is greater than the downslope gravitational shear stress, that is $S_{r}>\tau_{s}$. Downslope movement can occur only while external downslope stresses, earthquake loading in this case, are acting. A condition of momentary instability of a coherent block results as sediment undergoes nondisintegrative strain during transient earthquake loading (Whitman, 1985). Sediment states 


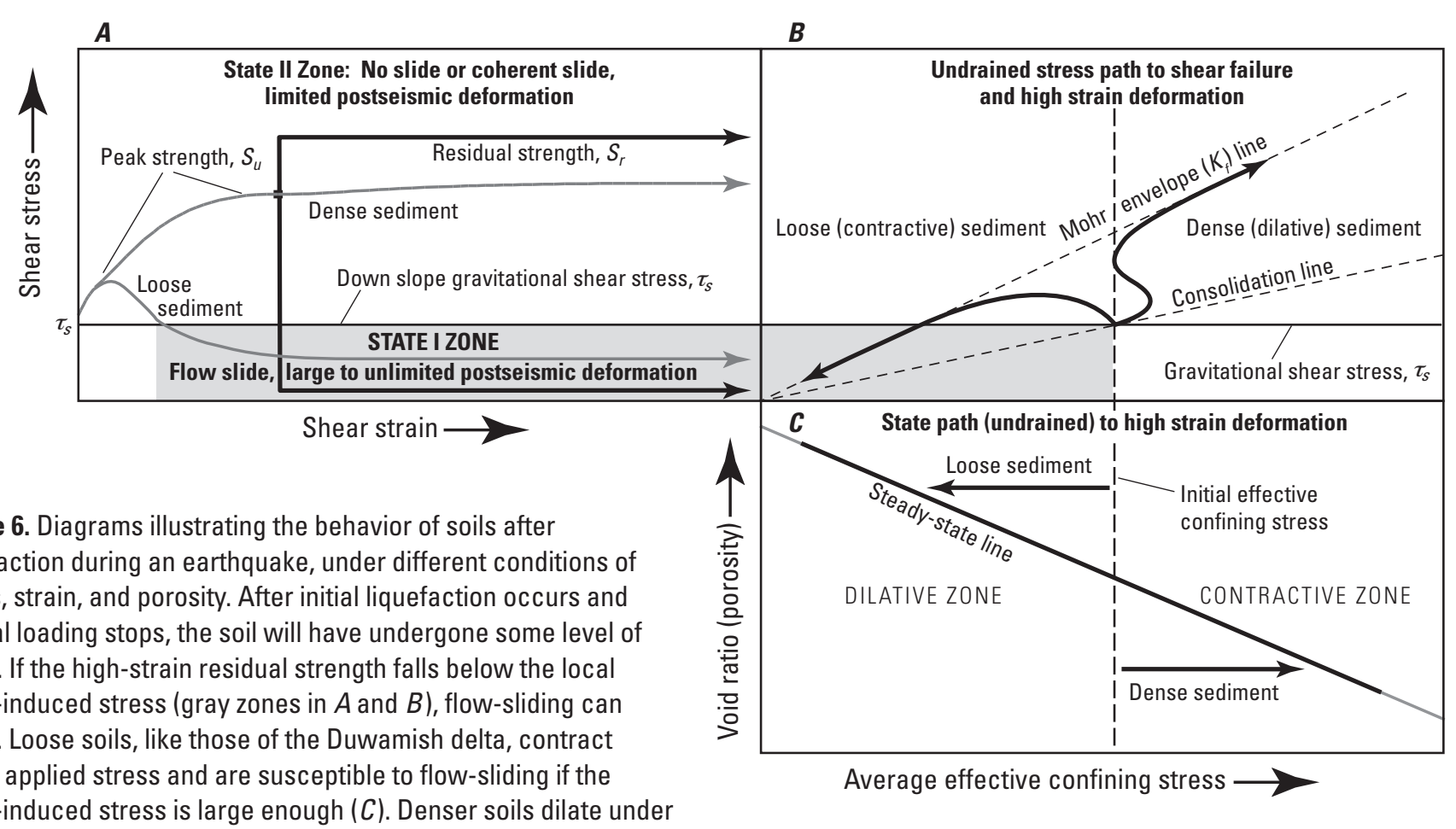

slope-induced stress is large enough $(C)$. Denser soils dilate under stress and do not flow-slide unless they are transformed into a looser state.

can be distinguished by the undrained effective stress response to applied shear (Whitman, 1985).

Disintegrative flow (State I sediment behavior) can occur in contractive sediment if the resistive shear stress at high strain, $S_{r}$, falls below the downslope gravitational shear stress, $\tau_{s}$ (Whitman, 1985). For example, in figure $6 A, \tau_{s}$ is initially less than the sediment peak undrained strength, $s_{u}$, and hence the slope is stable. During earthquake loading, additional stresses are superimposed upon any preexisting stresses. The peak shear strength, $s_{u}$, is reached and then shear resistance falls to $S_{r}$ because of the increased pore pressure and strain softening resulting from liquefaction. If $S_{r}<\tau_{s}$, straining of sediment can continue after the earthquake inertial loads are removed, because of the downslope stress disequilibrium. The result is an accelerating and disintegrating soil gravity flow.

A useful diagram for presenting those responses is the effective stress path, a plot of the shear stress, $q$, versus the average 2-dimensional effective confining stress, $p^{\prime}$ (fig. 6). Applied shear stress and normal effective confining stress are calculated for a plane of maximum shear stress during a triaxial compression test. During undrained shear, loose and volumetrically contractive sediment develops positive pore pressure that lowers the effective confining stress and causes the stress path to bend to the left (fig. 6B). At the onset of shearing of such sediment, a peak shear stress, $s_{u}$, is quickly reached, typically within 1 to 2 percent strain (Castro, 1969). At further strain, sediment fabric collapses on the interstitial pore water so rapidly that excess pore pressure cannot be expelled. A common result of undrained, contractive behavior is a marked drop in shear resistance (figs. 6A, $B$ ).

In contrast, State II sediment typically exhibits only slightly contractive to dilative behavior. Dilation, or the tendency toward volumetric increase during shear, causes a reduction of pore-water pressure. The result is a monotonic increase in shear stress that is supported even at high strains (fig. 6A). The stress path for dilative soil in State II climbs continuously toward and along the Mohr-Coulomb failure envelope on figure $4 B$. State II sediment develops a $S_{r}$ at large strains greater than $\tau_{s}$. If the earthquake loads that initiated failure are removed, the remaining shear resistance is sufficient to offset the downslope gravitational stress, and straining ceases. That is, the sediment mass becomes stable after external loading conditions are removed.

To assess the potential for flow failure of the Duwamish delta slope, a balance must be made of the downslope gravitational stresses induced by self-weight and the resistive residual strength of the soil mass. At a given subbottom depth, the downslope gravitational driving shear stress is a function of the sediment buoyant density and sea-floor slope angle. The resistive residual strength of the delta sediment was estimated by the relation proposed by Baziar and Dobry (1995) for silty sand. Using the soil boring logs of the delta front, we computed residual strengths from the SPT dataset for units of clean sand and silty sand deposits using a mean profile through the zone of likely residual strengths reported by Baziar and Dobry (1995). 


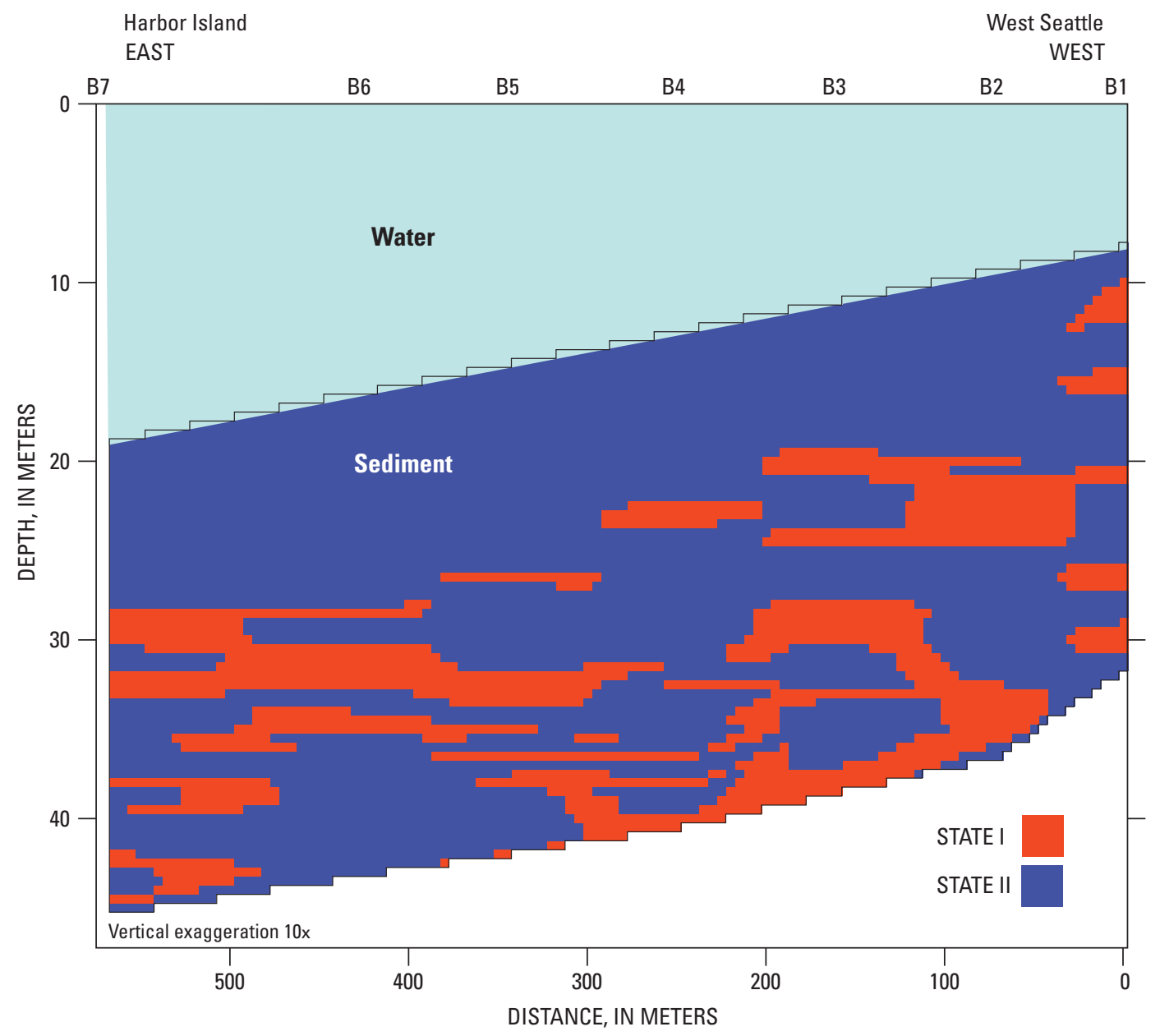

Figure 7. State analysis of the Duwamish delta front along the B1-B7 profile parallel to shore. State I indicates high disintegrative flow failure potential, whereas State II indicates potential for failure in a nonflow mode.

The ratio of $S_{r}$ to $\tau_{s}$ leads to a binary 'State' solution, in which soil elements with values greater than 1.0 were assigned a State II condition (coherent movement without flow failure potential) and those with values equal to or below 1.0 are assigned a State I condition (flow-failure potential). Zones between boreholes were interpolated with a linear stretch-fit using the program ArcInfo. In the upper $10 \mathrm{~m}$ of the sediment column at the delta front, the resisting residual strength exceeds the downslope gravitational stress for almost the entire cross section (fig. 7). Disintegrative flow failure in this upper portion of the delta sediment is not predicted on the basis of the state property analysis. Rather, the sediment could move small distances in an inertially driven landslide event as a relatively coherent mass; that is, it is largely in State II.

At depths below $10 \mathrm{~m}$, State I and State II conditions are interspersed throughout the soil mass. Although a State I condition implies that disintegrative flow failure can occur in a specific soil element within this zone, isolated State I zones within a matrix of State II soil will likely respond in a State II deformational mode. However, at the Duwamish River delta front, the analysis suggests that State I soil elements extend broadly, though not continuously, throughout the cross-section. If inertial earthquake loads are sufficiently strong (that is, close-in $M_{w}>7.0$ and $a_{\max }>0.2 \mathrm{~g}$ to $0.3 \mathrm{~g}$ ) and can strain deeper sediment into a residual-state condition, then disintegrative flow failure may occur. If this is the case, we expect a slide morphology of relatively coherent material rafted upon a deep-seated disintegrative-flow layer. Movement would cease when the slope angle diminished or if the slide mass thinned during shear, either of which reduces $\tau_{s}$. This analysis suggests that the overlying material, perhaps including portions of the waterfront facilities, would be transported down the flank of the Duwamish delta slope and might not restore gravitational stability before becoming submerged beneath the waters of Puget Sound. 


\section{Discussion and Conclusions}

Stratigraphic investigation of the Duwamish River valley, as well as those of the Puyallup and Nisqually Valleys currently under investigation by the authors, form the basis of an evolutionary model for Holocene deltas in Puget Sound. Evolution of the deltas was strongly influenced by the relic topography of the Puget Lowland, especially the geometry of glacial valleys that were deeply cut into Pleistocene outwash and till. Marine embayments replaced Late Pleistocene ice in the deeper parts of the valleys, which then became the loci of intense deltaic deposition. Large pulses of sediment, mainly the result of lahars from Mount Rainier, were funneled into the narrow valleys. The meandering river channels, like those that exist today, were probably overwhelmed by the episodically high volumes of volcaniclastic debris (Barnhardt and others, 1998; Barnhardt and Sherrod, 2006). Unable to transport the massive load, the single channel was replaced by a braided stream, with numerous shallow channels spread across a wide flood plain. After some undetermined time, sediment supplies decreased and a meandering system was reestablished, albeit in a different location than before. Although their full extent is unclear, the abandoned preeruption channels apparently meander across the muddy deltas as narrow ribbons of sand (fig. 3), which remain susceptible to liquefaction during large earthquakes.

The deltas grew rapidly seaward and, as sea level rose, aggraded and progressively buried older deltas (figs. 2,3). On the basis of the present location of the Duwamish delta relative to its positions at 5,700 years ago, Dragovich and others (1994) estimated an averaged progradation rate of $6.0 \mathrm{~km} / \mathrm{k} . \mathrm{y}$. Progradation rates may be significantly higher for short time intervals during the main impact of lahar events.

Earthquake-induced failure of the Duwamish delta front is a significant threat, especially where port facilities are built on thick, unconsolidated, sandy sediment adjacent to submarine slopes of 4-6 degrees. Analysis of the stability of the Holocene deltaic deposits using field penetration test data indicates that extensive soil liquefaction and ground failure of native deltaic deposits are likely during moderate to large earthquake events. Under expected levels of seismic loading, the analysis of deltaic material of the Duwamish river indicates a high potential for liquefaction for the delta under likely earthquake scenarios for the City of Seattle. An investigation of the state properties of native soil using field data indicates that large-strain flow failure may occur at the delta front along the northern end of Harbor Island.

\section{Acknowledgments}

This study was supported by the Western Coastal and Marine Geology project on CASCADIA Earthquake Hazards. John Tinsley and Brad Carkin are thanked for their reviews of the manuscript. Carol Reiss, Dianne Minasian, and Florence Wong contributed their expertise in producing GIS crosssections of the Duwamish river delta. Homa J. Lee, Phoebe
Deyhem, and Byron Richards assisted in the acquisition of radar and seismic field data.

\section{References}

Atwater, B.F., and Moore, A.L., 1992, A tsunami about 1000 years ago in Puget Sound, Washington: Science, v. 258, p. 1614-1617.

Barnhardt, W.A., and Sherrod, B.L., 2006, Evolution of a Holocene delta driven by episodic sediment delivery and coseismic deformation, Puget Sound, Washington, USA: Sedimentology, v. 53, no. 6, p. 1211-1228, doi:10.1111/ j.1365-3091.2006.00809.

Barnhardt, W.A., Kayen, R.E., Palmer, S.P., Pringle, P.T., and Atwater, B.F., 1998, Geology of Holocene deltas at Puget Sound, Washington: Proceedings of the 8th Congress of the International Association of Engineering Geologists, Vancouver, Canada, September 21-25, 1998.

Baziar, M.H., and Dobry, R., 1995, Residual strength and large-deformation potential of loose silty sand: Journal of Geotechnical Engineering, v. 121, no. 12, p. 896-906.

Booth, D.B., 1987, Timing and processes of deglaciation along the southern margin of the Cordilleran ice sheet, in Ruddiman, W.F., and Wright, H.E., Jr., eds, North America and adjacent oceans during the last glaciation: Boulder, Colorado, Geological Society of America, The Geology of North America, v. K-3, p. 71-90.

Booth, D.B., 1994, Glaciofluvial infilling and scour of the Puget Lowland, Washington, during ice-sheet glaciation: Geology, v. 22, p. 695-698.

Bray, J.D., Sancio, R.B., Kammerer, A.M., Merry, Scott, Rodriguez-Marek, Adrian, Khazai, Bijan, Chang, Susan, Bastani, Ali, and Collins, Brian, 2001, Some observations and geotechnical aspects of the February 28, 2001, Nisqually earthquake in Olympia, south Seattle, and Tacoma, Washington: Pacific Earthquake Engineering Research Center.

Brocher, T.M., Blakely, R.J., Fisher, M.A., Wells, R.E., and Christensen, N.I., 2000, Evidence for the Tacoma fault in the Puget Lowland, Washington; results from the 1998 Seismic Hazards Investigation in Puget Sound (SHIPS): Supplement to Eos, (American Geophysical Union Transactions), v. 81, p. 871.

Brocher, T.M., Parsons, T., Blakely, R.J., Christensen, N.I., Fisher, M.A., Wells, R.E., and the SHIPS Working Group, 2001, Three-dimensional geometry of crustal faults, basins, and uplifts in Puget Lowland, Washington; results from SHIPS, the 1998 Seismic Hazards Investigation in Puget Sound: Journal of Geophysical Research, v. 106, no. B7, p. 13541-13564. 
Bucknam, R.C., Hemphill-Haley, E., and Leopold, E., 1992, Abrupt uplift within the past 1700 years at southern Puget Sound, Washington: Science, v. 258, p. 1611-1614.

Campbell, S.K., 1981, The Duwamish no. 1 site; a lower Puget Sound shell midden: University of Washington, Institute for Environmental Studies, Office of Public Archaeology, Research Report, 564 p.

Castro, G., 1969, Liquefaction of sands: Cambridge, Massachusetts, Harvard University, Ph.D. dissertation, 111 p.

Cetin, K.O., Seed, R.B., Armen Der Kiureghian, M., Tokimatsu, K., Harder, L.F., Jr., Kayen, R.E., and Moss, R.E.S., 2004, SPT-based probabilistic and deterministic assessment of seismic soil liquefaction potential: Journal of Geotechnical and Geoenvironmental Engineering, v. 130, no. 12, p. 1314-1340.

Crandell, D.R., 1971, Postglacial lahars from Mt. Rainier volcano, Washington: U.S. Geological Survey Professional Paper 677, 75 p.

Dragovitch, J.D., Pringle, P.T., and Walsh, T.W., 1994, Extent and geometry of the Holocene Osceola Mudflow in the Puget Lowland-implications for Holocene sedimentation and paleography: Washington Geology, v. 22, p. 3-26.

Filiatrault, Andre, Uang, C.-M., Folz, Bryan, Christopoulos, Constantin, and Gatto, Kip, 2001, Reconnaissance report of the February 28, 2001 Nisqually (Seattle-Olympia) earthquake: San Diego, University of California, Department of Structural Engineering, 62 p. [http://www.eeri.org/lfe/pdf/ usa_nisqually_ucsd_reconnaissance_report.pdf, accessed June 25, 2001].

Jacoby, G.C., Williams, P.L., and Buckley, B.M., 1992, Tree ring correlation between prehistoric landslides and abrupt tectonic events in Seattle, Washington: Science, v. 258, p. 1621-1623.

Johnson, S.Y., Potter, C.J., and Armentrout, J.M., 1994, Origin and evolution of the Seattle Fault and Seattle basin, Washington: Geology, v. 22, p. 71-74.

Johnson, S.Y., Dadisman, S.V., Mosher, D.C., Blakeley, R.J., and Childs, J.R., 2001, Active tectonics of the Devils Mountain fault and related structures, northern Puget Sound, Washington; implications for earthquake hazards: Geological Society of America Bulletin, v. 111, p. 1042-1053.

Karlin, R.E., and Abella, S.E.B., 1992, Paleoearthquakes in the Puget Sound region recorded in sediments from Lake Washington, USA: Science, v. 258, p. 1617-1620.

Kayen, R.E., and Mitchell, J.K., 1997, Assessment of soil liquefaction during earthquakes by Arias intensity: Journal of Geotechnical and Geoenvironmental Engineering, v. 123, no. 12, p. 1162-1175.
Moss, R.E.S., Seed, R.B., Kayen, R.E., Stewart, J.P., and Der Kiureghian, A., 2006, Probabilistic seismic soil liquefaction triggering using the CPT: Journal of Geotechnical and Geoenvironmental Engineering, v. 132, no. 8, ISSN 10900241 .

National Research Council, 1985, Liquefaction of soils during earthquakes: National Academy Press, Report No: CETSEE-001, 240 p.

Nisqually Earthquake Clearinghouse Group 2001, The Nisqually earthquake of 28 February 2001: Seattle, University of Washington, $29 \mathrm{p}$.

Palmer, S.P., Pringle, P.T., and Schulene, J.A., 1991, Analysis of liquefiable soils in Puyallup, Washington, in Borcherdt, R.D., and Shah, H.C., eds., Proceedings of the Fourth International Conference on Seismic Zonation, EERI, Stanford, California, v.2, p. 621-628.

Poulos, S.J., 1981, The steady state of deformation: Journal of Geotechnical Engineering, v. 107, no. GT5, p. 553-562.

Poulos, S.J., Castro, G., and France, J.W., 1985, Liquefaction evaluation procedure: Journal of Geotechnical Engineering, v. 111 , no. 6., p. 772-791.

Pringle, P.T., and Palmer, S.P., 1992, Liquefiable volcanic sands in Puyallup, Washington, correlate with Holocene pyroclastic flow and lahar deposits in upper reaches of the Puyallup River valley [abs.]: Geological Society of America Abstracts with Programs, v. 24, no. 5, p. 76.

Pringle, P.T., Boughner, J.A., Vallance, J.W., and Palmer, S.P., 1997, Buried forests and sand deposits containing Mount Rainier andesite and pumice show evidence for extensive laharic flooding from Mount Rainier in the lower Duwamish valley, Washington: 2nd Symposium on the Hydrogeology of Washington: Olympia, Washington, p. 5.

Scott, K.M., Vallance, J.W., and Pringle, P.T., 1995, Sedimentology, behavior, and hazards of debris flows at Mount Rainier, Washington: U.S. Geological Survey Professional Paper 1547, 56 p.

Seed, H.B., 1987, Design problems in soil liquefaction: Journal of Geotechnical Engineering, v. 113, no. 8, p. 827-845.

Seed, R.B., and Harder, L.F., Jr., 1990, SPT-based analysis of cyclic pore pressure generation and undrained residual strength, in Duncan, J.M., ed., H. Bolton Seed Memorial Proceedings: Vancouver. B.C., BiTech Publishers, v. 2, p. 351-376,

Seed, H.B., Idriss, I.M., and Arango, I., 1983, Evaluation of liquefaction potential using field performance data: Journal of Geotechnical Engineering, v. 109, no. 3, p. 458-482. 
Seed, H.B., Tokimatsu, K., Harder, L.F., and Chung, R.M., 1984, Influence of SPT procedures in soil liquefaction resistance evaluation: University of California, Berkeley, Earthquake Engineering Research Center, Report no. UCB/ EERC-84/15, $50 \mathrm{p}$.

Vallance, J.W., and Scott, K.M., 1997, The Osceola Mudflow from Mount Rainier; sedimentology and hazard implications of a huge clay-rich debris flow: Geological Society of America Bulletin, v. 109, p. 143-163.

Whitman, R.V., 1985, On liquefaction: Proceedings Eleventh International Conference on Soil Mechanics and Foundation Engineering, San Francisco, vol. 4, p. 1923-1926.

Williams, H.F.L., and Roberts, M.C., 1989, Holocene sealevel change and delta growth-Fraser River delta, British Columbia: Canadian Journal of Earth Sciences, v. 26, p. 1657-1666.

Youd, T.L., and Perkins, M., 1978, Mapping liquefactioninduced ground failure potential: Journal of Geotechnical Engineering, v. 104, no. 4, p. 433-446.

Youd T.L., Idriss, I.M., Andrus, R.D., Arango, I., Castro, G., Christian, J.T., Dobry, R., Finn, W.D.L., Harder, L.F., Hynes, M.E., Ishihara, K., Koester, J.P., Liao, S.S.C., Marcuson, W.F., III, Martin, G.R., Mitchell, J.K., Moriwaki, Y., Power, M.S., Robertson, P.K., Seed, R.B., and Stokoe, K.H., II, 2001, Liquefaction resistance of soils; summary report from the 1996 NCEER and 1998 NCEER/NSF workshops on evaluation of liquefaction resistance of soils: Journal of Geotechnical and Geoenvironmental Engineering, v. 127, no. 10, p. $817-833$. 

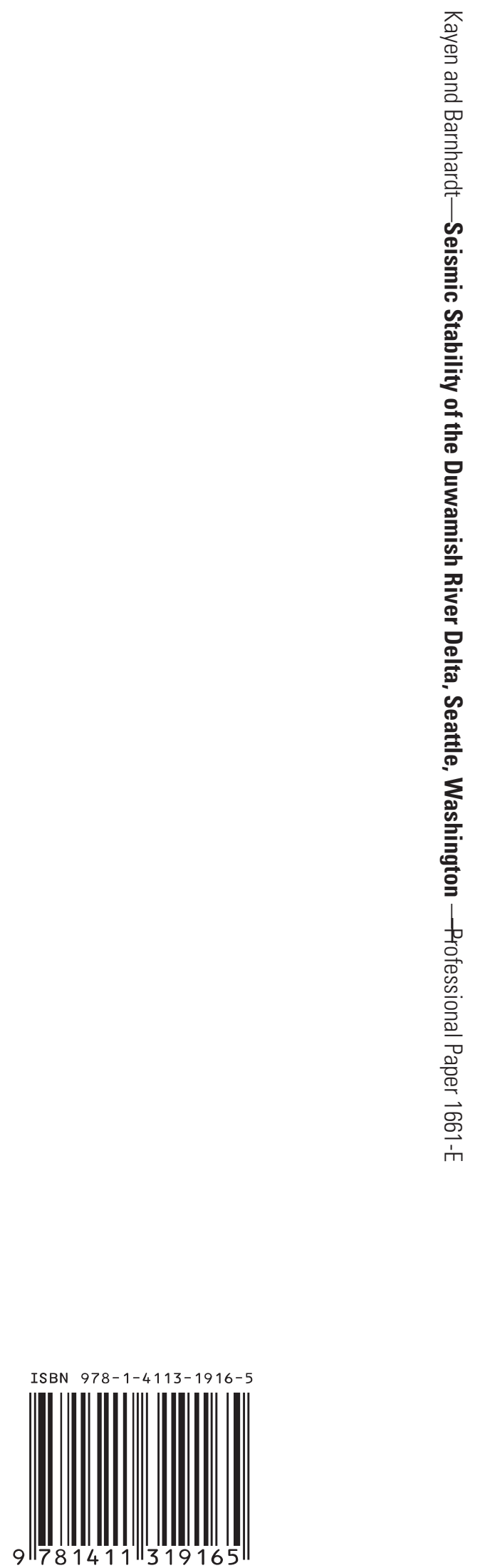